\title{
КОМПЛЕКСЫ СВИНЦА САЗАКРАУН-ЭФИРАМИ \\ КАК ПОТЕНЦИАЛЬНЫЕ КОМПОНЕНТЫ IN VIVO \\ ГЕНЕРАТОРОВ ДЛЯ ТЕРАПИИ ОНКОЛОГИЧЕСКИХ ЗАБОЛЕВАНИЙ
}

\author{
Л. Замуруева', Б. Егорова', А. Зубенко ${ }^{2}$ А. Пашанова² \\ ${ }^{1}$ Московский Государственный Университет им. М.В. Ломоносова, \\ Химический факультет, Москва, Россия \\ ${ }^{2}$ ИНЭОС РАН им. А.Н. Несмеянова
}

DOI: 10.19163/MedChemRussia2021-2021-128

E-mail: Lyubovzam@mail.ru

Альфа-излучатели более эффективны для направленной лучевой терапии и менее токсичны при циркуляции в организме из-за малого радиуса воздействия по сравнению с бета-излучателями. Например, изотоп висмута ${ }^{212} \mathrm{Bi}$ перспективен для ядерной медицины, однако его относительно небольшой период полураспада (61 мин) ограничивает его использование. Биомолекулы могут быть конъюгированы с ${ }^{212} \mathrm{~Pb}$, более долгоживущим материнскимрадионуклидом ${ }^{212} \mathrm{Bi}$ с периодом полураспада 10,6 ч, который будет генерировать целевой радионуклид непосредственно в организме. Много работ с данной генераторной парой посвящено хелаторуDOTA, который образует прочные комплексы с катионами свинца и висмута, однако, для прочного связывания требуется нагревание. Было показано, что около трети висмута высвобождается из комплекса с DOTA в результате распада ${ }^{212} \mathrm{~Pb}$ и не связывается повторно. Такую проблему может решить использование хелаторов с быстрой кинетикой связывания висмута без нагревания.

В данной работе изучалось комплексообразование катионов свинца с азакраун-эфирами, отличающимися между собой размером гетероцикла и наличием заместителей. Были определены константы устойчивости методом потенциометрического титрования. Комплексы с наибольшими константами $\left(\lg \beta=14,1 ; 17,2 ; 20,1\right.$ и 15,6) затем были получены с ${ }^{210} \mathrm{~Pb}$, была подобрана TCX система для определения радиохимической чистоты комплексов и определены оптимальные концентрации лигандов и буферный агент. Устойчивость полученных комплексов была изучена в жидкостях биологического назначения. Все четыре комплекса оказались устойчивыми в изотоническом растворе и растворах катионов микроэлементов в течение 24 часов. В девятикратном избытке сыворотки крови два из рассматриваемых комплекса оказались устойчивыми в течение 24 часов, а остальные диссоциировали на 20\% за то же время.

Работа выполнена при поддержке гранта РНФ 18-73-10035

$$
-128-
$$

